\title{
Effects of shell lesions on survival, growth, condition and reproduction in the New Zealand blackfoot abalone Haliotis iris
}

\author{
Hendrik H. Nollens, Jonathan A. Keogh, P. Keith Probert* \\ Department of Marine Science, University of Otago, PO Box 56, Dunedin 9001, New Zealand
}

\begin{abstract}
The pathogenicity of shell lesions in Haliotis iris Martyn was examined in a laboratory experiment in which 73 apparently healthy and 106 lesion-bearing abalone were maintained for up to $12 \mathrm{mo}$. The abalone were collected from the wild and kept in cages (1 ind. cage ${ }^{-1}$ ) for 4,8 or $12 \mathrm{mo}$, at which times estimates of survival, growth, condition and reproductive capacity were made for each of 3 groups: 'healthy' $(\mathrm{n}=73)$, 'mildly affected' $(\mathrm{n}=61)$ and 'severely affected' $(\mathrm{n}=32)$. Unaffected abalone showed a $2.7 \%$ mortality $(n=73)$ compared to $7.5 \%(n=93)$ in lesion-bearing individuals over the entire experiment. Growth rates were significantly decreased in mildly and severely affected abalone: the relative von Bertalanffy growth coefficient $(K)$, calculated over 12 mo, was -0.176 for unaffected, -0.079 for mildly affected and -0.048 for severely affected individuals. The asymptotic length $\left(\mathrm{L}_{\infty}\right)$ was calculated to be $131.5 \mathrm{~mm}$ for unaffected, $142.1 \mathrm{~mm}$ for mildly affected and $150.3 \mathrm{~mm}$ for severely affected abalone. Significantly $(\mathrm{p}<0.05)$ lower condition indices and decreased reproductive capacity $(p>0.05)$ were obtained for the severely affected group compared to unaffected abalone. These trends were consistent over the course of the experiment.
\end{abstract}

KEY WORDS: Abalone - Haliotis · Gastropoda - Shell lesion · Mortality · Growth · Condition · Reproductive capacity

Resale or republication not permitted without written consent of the publisher

\section{INTRODUCTION}

Shell lesions were recently reported and illustrated for 3 New Zealand species of Haliotis (H. iris Martyn, $H$. australis Gmelin and $H$. virginea virginea Gmelin) (Grindley et al. 1998). The lesions were described as blisters of conchiolin, and occasionally nacreous material, located on the inside of the shell near the apex. No gross pathological changes were observed in any of the soft tissues. Lesions were most prevalent in wild populations of $H$. iris in South Otago and Stewart Island, with prevalences of up to $70 \%$ (Grindley et al. 1998). The aetiology of this condition is at present unknown, but shell-boring organisms are implicated (Friedman et al. 1997, Grindley et al. 1998).

Several reports exist of shell irregularities in abalone caused by shell-boring organisms (Kojima \& Imajima 1982, Clavier 1992, Oakes \& Field 1996, Dunphy 1999). In some instances, shell abnormalities have been shown to have a dramatic effect on the condition and growth of affected individuals. For example, Kojima \& Imajima (1982) found that the flesh weight of Japanese abalone Haliotis diversicolor aquatilus decreased significantly when the shell was infested by more than 10 polydorid polychaetes. Likewise, aquaculturalists have reported that shell lesions in $H$. iris could be fatal to individuals in captivity (Grindley et al. 1998). Grindley et al. (1998) also showed that in 4 of 11 wild populations sampled, the mean shell length of lesion-bearing $H$. iris was significantly less $(p<0.05)$ than that of apparently healthy individuals from the same site. In addition, Grindley (1997) reported 50\% mortality in lesion-bearing $H$. iris $(\mathrm{n}=28)$ over a 6 mo period compared to $26 \%$ mortality in apparently healthy abalone $(\mathrm{n}=31)$. However, small sample sizes and the high level of mortality in control individuals (Grindley, 1997) suggests that further studies in this area are warranted. The present study was therefore designed 
to collect detailed information on survival, growth, condition and reproductive capacity of lesion-bearing and non lesion-bearing $H$. iris held in a laboratory setting for up to 12 mo.

\section{MATERIALS AND METHODS}

On 3 December 2000, 182 abalone (Haliotis iris Martyn) were collected using SCUBA from Jack's Bay $\left(46^{\circ} 33^{\prime} \mathrm{S}, 169^{\circ} 36^{\prime} \mathrm{E}\right)$, Otago, SE New Zealand. This sample size was calculated to detect an increase in mortality rates from $25 \%$ in unaffected to $50 \%$ for affected abalone (Grindley 1997), with an accepted alpha error rate of $5 \%$ and a power $(1-\beta)$ of 0.8 . Upon collection, the abalone were transported live to the Portobello Marine Laboratory near Dunedin. They were weighed to the nearest $0.1 \mathrm{~g}$ and the shell length was measured to the nearest $1 \mathrm{~mm}$ using callipers. Each individual was uniquely marked with a random 4-digit number, using $15 \mathrm{~mm}$ plastic tags fixed to the shell with acrylic adhesive. The tags were positioned on the anterior of the shell, on the opposite side to the respiratory pores. All abalone were anaesthetised and screened for shell lesions using endoscopy as described in Nollens et al. (2002) and diagnosed as 'affected' or 'unaffected'. After screening, the abalone were randomly allocated to individual $17.5 \times 27.5 \times$ $12.5 \mathrm{~cm}$ LabProduct ${ }^{\circledR}$ polycarbonate rodent cages and positioned on a purpose-built shelf system. The shelf order was changed monthly in an attempt to ensure similar light and water-pressure treatments amongst all cages. Each cage was individually supplied with flow-through sand-filtered seawater at approximately $380 \mathrm{ml} \mathrm{min}^{-1}$ and was cleaned weekly. The abalone were fed the macroalga Macrocystis pyrifera Bory, ad libitum, which was replenished twice weekly. Direct contact between individuals was avoided. The cages were inspected twice daily and dead individuals removed. The dead abalone were immediately dissected to determine cause of death.

On 3 April 2001, 4 mo into the experiment, 22 randomly selected unaffected and 22 randomly selected affected abalone were shucked. Sex and presence/ absence of lesions were noted, and the soft tissues were examined for signs of disease. Shell length, total weight, wet shell weight and soft body weight were measured to the nearest $1 \mathrm{~mm}$ or $0.1 \mathrm{~g}$. The height of the conical appendage was recorded to the nearest $1 \mathrm{~mm}$ as described in Hahn (1989), after which it was excised and fixed in Davidson's formaldehyde solution (Bucke 1972). It was later transferred to $70 \%$ ethanol and processed for histological analysis. Shells were oven-dried at $60^{\circ} \mathrm{C}$ and dry shell weight was recorded to the nearest $0.1 \mathrm{~g}$.
On 6 August 2001, 44 further, randomly selected abalone were shucked. They were dissected, sexed and the presence of lesions noted. The soft tissues of all individuals were examined for signs of disease. Shell length, total weight, dry and wet shell weight, soft body weight and height of the conical appendage were recorded as before. The conical appendages were excised and frozen at $-20^{\circ} \mathrm{C}$ for further calculation of gonad indices. On 13 December 2001, the experiment was concluded, and the remaining abalone were processed as in the previous August harvest.

The length and width of both shells and lesions were measured to the nearest $1 \mathrm{~mm}$ and recorded. Lesion and shell surface area $\left(\mathrm{mm}^{2}\right)$ were estimated using the formula for the calculation of the surface area of an ellipse:

$$
\text { Surface ellipse }=r 1 \times r 2 \times \pi
$$

Relative lesion area (\%) was calculated using the following formula:

$$
\text { Relative lesion area }=\frac{\text { Lesion surface area }}{\text { Shell surface area }} \times 100
$$

For analysis, lesion-bearing individuals were divided into mildly affected (relative lesion area $<10 \%$ ) and severely affected (relative lesion area $\geq 10 \%$ ) groups and compared with unaffected abalone.

Growth rates. After 4, 8 and 12 mo of monitoring, the length increment of the abalone allocated to the unaffected, mildly affected and severely affected group was plotted against their respective initial lengths. From these graphs, Manzer \& Taylor regression equations were obtained for each group (Poore 1972). All regressions were tested for significance of slope and homogeneity of slopes using Student's $t$-test (McShane \& Naylor 1995, Zar 1999). The von Bertalanffy growth parameters, the relative growth coefficient, $K$, and asymptotic length, $\mathrm{L}_{\infty}(\mathrm{mm})$, were derived from the regression equation for each group, as described in Beverton \& Holt (1993). The von Bertalanffy growth curves, calculated from the 12 mo growth increments, were plotted for each group of abalone.

Condition indices. We calculated 2 condition indices (CI) for all abalone using the following formulas:

$$
\begin{gathered}
\text { CI -1 = } \frac{\text { Total wet weight }- \text { Wet shell weight }}{\text { Total wet weight }} \\
\text { (Friedman et al. 1997) } \\
\text { CI - } 2=\frac{\text { Wet soft tissue weight }}{\text { Wet shell weight }} \\
\text { (Lucas \& Beninger 1985) }
\end{gathered}
$$

A third condition index was calculated using dried shell weight, rather than wet shell weight; this removes 
much of the variability associated with the free fluid in the shell:

$$
\text { CI }-3=\frac{\text { Wet soft tissue weight }}{\text { Dried shell weight }}
$$

Gonad indices. Gonad dimensions were obtained as described in Hahn (1989), and the gonad volumes were estimated as:

Estimated gonad volume $=\frac{\pi h}{96} \times\left[8(x+y)^{2}-\frac{(x+y+a+b)^{3}}{x+y}\right]$

(Hahn 1989)

where $h=$ height of the conical appendage, $x=$ width of the conical appendage, $y=$ height of the conical appendage, $a=$ width of the digestive gland and $b=$ height of the digestive gland. The measurements $x, y$, $a$ and $b$ were all taken on a section midpoint of the conical appendage length (Hahn 1989).

We subsequently calculated 2 modified gonad bulk

$$
\begin{aligned}
\text { GBI }-1 & =\frac{\text { Estimated gonad volume }}{\text { Soft body weight }} \\
\text { GBI }-2 & =\frac{\text { Estimated gonad volume }}{\text { Total body weight }}
\end{aligned}
$$

indices (GBI) using the following formulas:

(Hahn 1989)

Formaldehyde-fixed gonads were prepared for histological examination by embedding in paraffin wax and sectioning at a thickness of $4 \mu \mathrm{m}$. Sections were mounted and then stained with haematoxylin-eosin, and oocyte size-frequency distribution curves were obtained following Hahn (1989).

\section{RESULTS}

\section{Mortality}

Over the 12 mo period, 12 mortalities occurred. Of these, 3 abalone (including 2 affected) died after having escaped from their cages and were excluded from further analysis. The remaining 9 mortalities involved 2 un- affected $(2.7 \%), 6$ mildly affected $(9.8 \%)$ and 1 severely affected (3.1\%) abalone (Table 1) (Kruskal-Wallis test statistic $=2.618, \mathrm{df}=2, \mathrm{p}>0.05)$. Necropsy revealed no gross abnormalities in the soft tissues of either the affected or unaffected abalone. Of the 12 mortalities, 5 occurred in the last 3 mo of the experiment (Table 1).

For each of the 4 and 8 mo sample collections, 3 (7\%) of the abalone originally diagnosed by endoscopy as unaffected displayed shell lesions on dissection. At the conclusion of the experiment, an additional 7 (8.5\%) of the originally unaffected abalone displayed shell lesions. The dimensions of these previously undetected lesions ranged between $1 \times 2 \mathrm{~mm}$ and $43 \times$ $28 \mathrm{~mm}$ (for $\mathrm{n}=13$, mean lesion surface area $=228 \pm$ $330 \mathrm{~mm}^{2}$ ). The 170 live abalone consisted of 71 unaffected, 67 mildly affected and 32 severely affected individuals at the time of harvest. The respective mean shell lengths of the 3 groups were $120.6 \pm 9.7 \mathrm{~mm}$, $122.2 \pm 7.6 \mathrm{~mm}$ and $120.0 \pm 8.5 \mathrm{~mm}$, and they were not significantly different (ANOVA, $F=0.889$, p > 0.10). Relative lesion surface area ranged between 0.02 and $9.4 \%$ (mean $=4.8 \pm 3.2 \%)$ in the mildly affected group and between 10.1 and $38.5 \%$ (mean $=15.0 \pm 5.5 \%$ ) in the severely affected group.

\section{Growth rates}

The growth rate $(K)$ of the unaffected Haliotis iris group was significantly ( $p<0.05$ ) higher than the growth rate of the severely affected group (Table 2). After both 8 and $12 \mathrm{mo}$, the growth rate of the mildly affected abalone was between the growth rates of the unaffected and severely affected groups (Table 2). The growth rate of the unaffected group progressively increased over the course of the experiment $(-0.091$, -0.129 and -0.176 after 4,8 and 12 mo respectively). The growth rate of the severely affected abalone progressively declined $(-0.082,-0.053$ and -0.048 after 4 , 8 and 12 mo respectively). The estimated asymptotic length $\left(\mathrm{L}_{\infty}\right)$ calculated over the full 12 mo period for unaffected, mildly affected and severely affected abalone was $131.5,142.1$ and $150.3 \mathrm{~mm}$ respectively

Table 1. Haliotis iris. Total number (N) of abalone, number (n) and approximate percentage mortality for each sampling period and for whole period (12 mo) of experiment in groups of abalone unaffected, or mildly and severely affected by shell lesions.

\begin{tabular}{|c|c|c|c|c|c|c|c|c|c|c|c|c|}
\hline & \multicolumn{3}{|c|}{$0-4 \mathrm{mo}$} & \multicolumn{3}{|c|}{$5-8 \mathrm{mo}$} & \multicolumn{3}{|c|}{$9-12 \mathrm{mo}$} & \multicolumn{3}{|c|}{ Total } \\
\hline & None & Mild & Severe & None & Mild & Severe & None & Mild & Severe & None & Mild & Severe \\
\hline $\mathrm{N}$ & 73 & 61 & 32 & 50 & 49 & 23 & 35 & 29 & 16 & 73 & 61 & 32 \\
\hline $\mathrm{n}$ & 1 & 2 & 0 & 0 & 1 & 0 & 1 & 3 & 1 & 2 & 6 & 1 \\
\hline$\%$ & 1.4 & 3.3 & 0.0 & 0.0 & 2.0 & 0.0 & 2.9 & 10.3 & 6.3 & 2.7 & 9.8 & 3.1 \\
\hline
\end{tabular}
Abalone that were diagnosed as unaffected by endoscopy but were found to be affected on dissection $(n=13)$ were excluded from all analyses together with 3 individuals that died during the first month after escaping from their cages 
Table 2. Haliotis iris. Sample size (n), relative growth coefficient $(K)$ and asymptotic length $\left(\mathrm{L}_{\infty}\right)$ for abalone unaffected, mildly affected and severely affected by shell lesions after 4, 8 and 12 mo in captivity

\begin{tabular}{|c|c|c|c|c|c|c|c|c|c|}
\hline & None & $\begin{array}{l}4 \text { mo } \\
\text { Mild }\end{array}$ & Severe & None & $\begin{array}{l}8 \text { mo } \\
\text { Mild }\end{array}$ & Severe & None & $\begin{array}{l}12 \text { mo } \\
\text { Mild }\end{array}$ & Severe \\
\hline $\mathrm{n}$ & 72 & 59 & 32 & 50 & 48 & 23 & 34 & 26 & 15 \\
\hline K & -0.091 & -0.080 & -0.082 & -0.129 & -0.117 & -0.053 & -0.176 & -0.079 & -0.048 \\
\hline $\mathrm{L}_{\infty}(\mathrm{mm})$ & 179.2 & 186.9 & 180.3 & 144.2 & 175.7 & 176.3 & 131.5 & 142.1 & 150.3 \\
\hline
\end{tabular}

(Table 2, Fig. 1). Values for $\mathrm{L}_{\infty}$ were consistently higher for the severely affected compared to the unaffected group. After both 8 and $12 \mathrm{mo} \mathrm{L}_{\infty}$ of the unaffected, mildly affected and severely affected groups all showed a progressive increase (Table 2). The slopes of the Manzer \& Taylor regression equations were all significant (slope $\neq 0, p<0.05$ ). The slopes calculated for both the mildly affected and the severely affected abalone differed significantly from the slope of the unaffected abalone at all times (Student's t-test: $\mathrm{p}<$ 0.05).

\section{Condition indices}

For all condition indices (CI-2, -2, -3), the severely affected abalone consistently yielded significantly lower ( $\mathrm{p}<0.05$ ) condition indices than unaffected individuals (Table 3). Condition indices of the mildly affected group were also consistently lower than those of the unaffected group, but higher than those of the severely affected group. The CI-3 scores were all significantly different $(\mathrm{p}<0.05)$ between the unaffected,

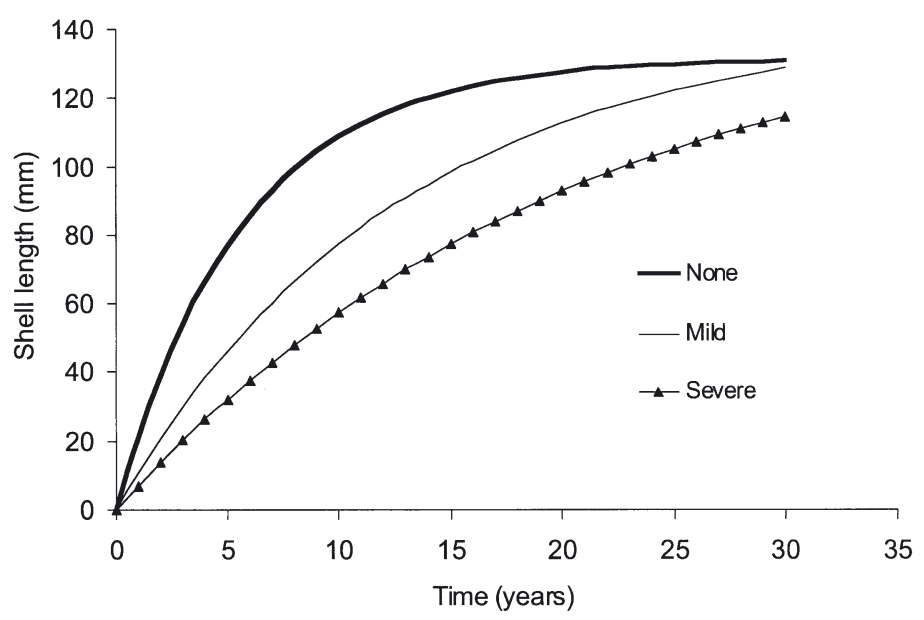

Fig. 1. Haliotis iris. von Bertalanffy growth curves, calculated from 12 mo growth increments, of abalone unaffected (None), mildly affected (Mild) and severely affected (Severe) by shell lesions mildly affected and severely affected groups. The CI-2 scores of the mildly affected and severely affected group were significantly different $(p<0.05)$ as well. The 3 condition scores calculated for both the mildly and the severely affected abalone were consistently lower for the 12 mo period than for the 8 mo period (Table 3). For CI-2 and CI-3 this decrease was significant $(p<0.05)$. The condition scores calculated for both the mildly and the severely affected abalone were also consistently lower for the 12 mo period compared to the 4 mo period. For CI-2 this difference was significant $(p<0.05)$. In all cases, the condition of the abalone did not vary significantly with shell length (ANCOVA, $\mathrm{p}>0.10)$.

\section{Gonad indices}

At 4, 8 and $12 \mathrm{mo}$, both gonad bulk indices (GBI-1 and GBI-2) were lower for severely affected individuals compared to both unaffected and mildly affected individuals (Table 4). The GBI-2 indices of mildly and severely affected abalone were also consistently significantly different $(p<0.05)$. After 4 and $8 \mathrm{mo}$, the unaffected abalone yielded the highest gonad bulk indices. After $12 \mathrm{mo}$, the gonad bulk indices calculated for the mildly affected abalone were highest. The mean gonad bulk indices of the 3 groups were significantly higher after 8 mo than at 4 or 12 mo $(\mathrm{p}<0.05)$. Neither the gonad bulk index GBI-1 nor GBI-2 varied significantly with shell length (ANCOVA, $p>0.05$ ) for any of the 3 groups. Oocyte size was not significantly different between unaffected $(\mathrm{n}=11)$, mildly affected ( $\mathrm{n}=7$ ) and severely affected abalone (for $\mathrm{n}=2, F=$ $0.810, p>0.10$ ), and no difference was observed in the oocyte size-frequency distribution between the 3 groups (Fig. 2).

\section{DISCUSSION}

Our experiment was designed to detect an expected increase of approximately $25 \%$ in risk of mortality for affected abalone compared to an unaffected control 
Table 3. Haliotis iris. Mean condition indices of abalone unaffected $(\mathrm{n}=71)$, mildly affected $(\mathrm{n}=67)$ and severely affected $(\mathrm{n}=$ 32) by shell lesions at time of sample collection. For each condition index (see 'Condition indices' in 'Materials and methods' for index calculation), results that were not significantly different $(\mathrm{p}>0.05)$ share same superscript

\begin{tabular}{|c|c|c|c|c|c|c|c|c|c|}
\hline \multirow[t]{2}{*}{ Lesion grade } & \multicolumn{3}{|c|}{ Condition Index 1} & \multicolumn{3}{|c|}{ Condition Index 2} & \multicolumn{3}{|c|}{ Condition Index 3} \\
\hline & $4 \mathrm{mo}$ & $8 \mathrm{mo}$ & $12 \mathrm{mo}$ & $4 \mathrm{mo}$ & $8 \mathrm{mo}$ & $12 \mathrm{mo}$ & $4 \mathrm{mo}$ & $8 \mathrm{mo}$ & $12 \mathrm{mo}$ \\
\hline None & $0.643^{\mathrm{a}, \mathrm{e}}$ & $0.619^{c}$ & $0.612^{\mathrm{c}, \mathrm{e}}$ & $2.018^{\mathrm{a}}$ & $2.099^{\mathrm{a}}$ & $1.600^{\mathrm{c}}$ & $2.020^{\mathrm{a}}$ & $2.270^{\mathrm{a}, \mathrm{d}}$ & $2.048^{\mathrm{d}}$ \\
\hline Mild & $0.632^{\mathrm{a}, \mathrm{b}, \mathrm{e}, \mathrm{f}}$ & $0.605^{\mathrm{c}, \mathrm{d}}$ & $0.601^{\mathrm{c}, \mathrm{d}, \mathrm{e}, \mathrm{f}}$ & $1.916^{\mathrm{a}}$ & $1.884^{\mathrm{a}}$ & $1.531^{\mathrm{c}}$ & $1.959^{\mathrm{b}}$ & $2.036^{\mathrm{b}, \mathrm{e}}$ & $1.867^{\mathrm{e}}$ \\
\hline Severe & $0.611^{\mathrm{b}, \mathrm{f}}$ & $0.590^{\mathrm{d}}$ & $0.580^{\mathrm{d}, \mathrm{f}}$ & $1.675^{\mathrm{b}}$ & $1.704^{\mathrm{b}}$ & $1.403^{\mathrm{d}}$ & $1.791^{\mathrm{c}}$ & $1.832^{\mathrm{c}, \mathrm{f}}$ & $1.731^{\mathrm{f}}$ \\
\hline
\end{tabular}

Table 4. Haliotis iris. Mean $( \pm \mathrm{SE})$ modified gonad bulk indices, calculated as (estimated gonad volume:soft body weight) and (estimated gonad volume:total body weight) for abalone unaffected $(\mathrm{n}=70)$, mildly affected $(\mathrm{n}=67)$ and severely affected $(\mathrm{n}=$ 32) at time of sample collection. For each gonad index, results that were not significantly different $(p>0.05)$ from each other share same superscript

\begin{tabular}{|c|c|c|c|c|c|c|}
\hline \multirow[t]{2}{*}{ Lesion grade } & \multicolumn{3}{|c|}{ Modified Gonad Bulk Index 1} & \multicolumn{3}{|c|}{ Modified Gonad Bulk Index 2} \\
\hline & $4 \mathrm{mo}$ & $8 \mathrm{mo}$ & $12 \mathrm{mo}$ & $4 \mathrm{mo}$ & $8 \mathrm{mo}$ & $12 \mathrm{mo}$ \\
\hline None & $19.49^{\mathrm{a}} \pm 2.14$ & $33.88^{\mathrm{b}} \pm 2.70$ & $20.74^{\mathrm{a}} \pm 1.74$ & $12.58^{\mathrm{a}, \mathrm{b}} \pm 1.31$ & $21.39^{\mathrm{c}, \mathrm{d}} \pm 1.65$ & $12.67^{\mathrm{a}, \mathrm{b}} \pm 1.06$ \\
\hline Mild & $19.21^{\mathrm{a}} \pm 2.90$ & $28.24^{\mathrm{b}} \pm 2.16$ & $23.80^{\mathrm{a}} \pm 1.74$ & $12.15^{\mathrm{a}} \pm 1.77$ & $17.10^{\mathrm{c}} \pm 1.32$ & $14.25^{\mathrm{a}} \pm 1.07$ \\
\hline Severe & $18.18^{\mathrm{a}} \pm 3.18$ & $20.38^{\mathrm{b}} \pm 3.78$ & $19.87^{\mathrm{a}} \pm 2.58$ & $10.77^{\mathrm{b}} \pm 1.95$ & $11.99^{\mathrm{d}} \pm 2.32$ & $11.52^{\mathrm{b}} \pm 1.58$ \\
\hline
\end{tabular}

group (Grindley 1997). However, the observed mortality of unaffected and total affected individuals was 2.7 and $7.5 \%$ respectively (Table 1 ), and the power of this experiment design to detect this difference is less than 0.5. Nevertheless, the total mortality rate of lesionbearing abalone $(7.5 \%)$ was over double that of unaffected individuals $(2.7 \%)$, suggesting clearly that lesions directly or indirectly compromise the survival of affected abalone. Also, the mortality rate of mildly affected abalone $(9.8 \%)$ was higher than the mortality rate of severely affected abalone $(3.1 \%)$, suggesting that the acute phase of the shell disease may be more lethal than its chronic phase.

Of the abalone diagnosed as unaffected at the onset of the experiment, $13(7.1 \%)$ displayed shell lesions at the time of sample processing. These lesions were either misdiagnosed during the endoscopic examination at the onset of the experiment or were acquired during the monitoring period. Given that $7.1 \%$ incorrect diagnoses is within the diagnostic accuracy of the endoscopic method (Nollens et al. 2002), no conclusions can be drawn as to when these lesions were acquired. This is also in agreement with the results presented in Grindley (1997) in which $3(10 \%)$ of 31 Haliotis iris appeared to develop lesions of up to $18 \mathrm{~mm}$ diameter in less than $180 \mathrm{~d}$.

The incremental growth, determined as change in shell length, was significantly $(\mathrm{p}<0.05)$ reduced in all lesion-bearing abalone, but the reduction was particularly evident for more advanced lesions (Table 2, Fig. 1). Furthermore, the growth rates of unaffected individuals gradually increased over the length of the experiment, whereas the growth rates of severely affected abalone gradually decreased. Nonetheless, affected abalone were estimated to reach a larger size than unaffected individuals ( $\mathrm{L}_{\infty}$ of 150.3 and $131.5 \mathrm{~mm}$ respectively, calcu-

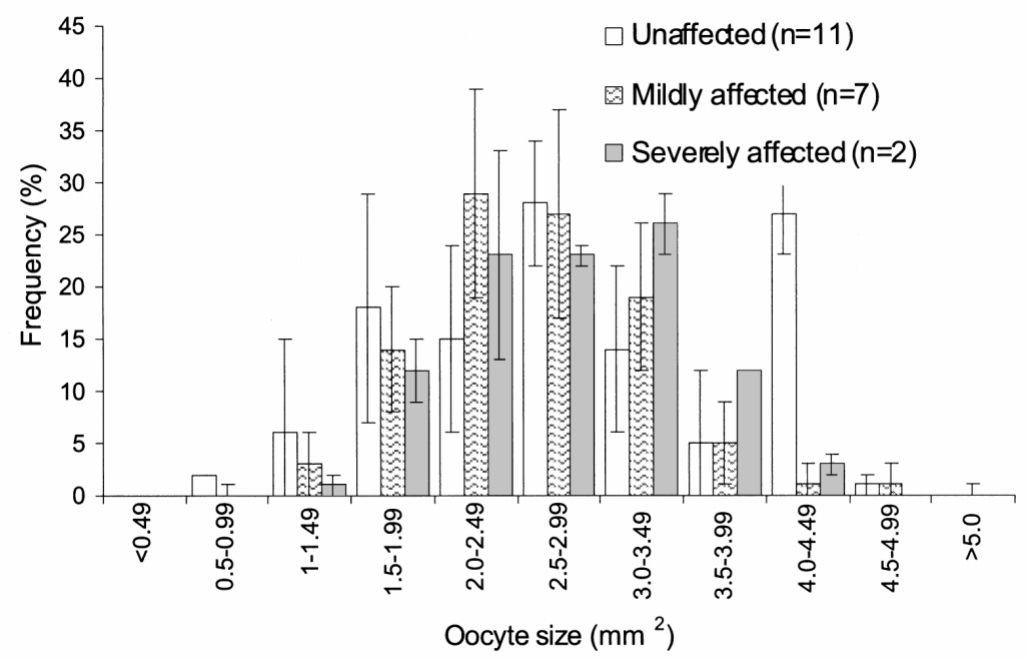

Fig. 2. Haliotis iris. Oocyte size-frequency distribution for abalone unaffected $(n=11)$, mildly affected $(n=7)$ and severely affected $(n=2)$ by shell lesions. Mean oocyte size was not significantly different between unaffected, mildly affected and severely affected individuals $(F=0.810$, $\mathrm{p}=0.46)$ 
lated over 12 mo) (Table 2, Fig. 1). However, this finding should be interpreted with caution, given the lack of small ( $<74 \mathrm{~mm}$ shell length) individuals in the sample set and the relatively short duration of the monitoring period. Grindley (1997) did not detect significant differences in growth between captive affected and unaffected Haliotis iris over $180 \mathrm{~d}(\mathrm{n}=32)$, although growth in some wild populations did show impairment (Grindley et al. 1998).

A similar negative relationship was established between relative lesion-surface area and all calculated condition and gonad indices (Tables 3 \& 4). Both condition and reproductive capacity of the severely affected abalone were especially impaired. This general physiological depletion was not reflected in the oocyte size distribution and maturation (Fig. 2). The findings from this experiment differ from the results of an earlier, small-scale analysis by Friedman et al. (1997), which failed to detect an influence of shell lesions on the condition score of Haliotis iris and $H$. australis ( $\mathrm{n}=17$ each). Furthermore, in the present study condition scores of unaffected individuals fluctuated over time, whereas the condition scores for the mildly and severely affected abalone generally decreased. For both gonad bulk indices, however, seasonality and shell length were of greater influence than disease status. The mean gonad bulk indices of these laboratory-held abalone peaked around August (Table 4), whereas spawning in wild populations of $H$. iris is expected to occur between February and May (Sainsbury 1982). It was also interesting to note the close correspondence between the 3 condition indices and between the 2 gonad indices used in this study. This suggests that the more easily obtained Condition Index 1 (Friedman et al. 1997), Condition Index 2 (Lucas \& Beninger 1985) and Gonad Index 2 (Hahn 1989) are adequate for assessment of condition and reproductive capacity in $H$. iris.

The results presented here on the monitoring of 73 apparently healthy and 106 affected abalone for up to 12 mo showed higher mortality, reduced growth, weakened physiological condition and decreased reproductive capacity amongst lesion-bearing abalone compared to controls. These trends were consistent for all parameters over the length of the experiment, and point to a general physiological cost of the shell condition to the abalone. Clavier (1992) and Dunphy (1999) concluded that shell pathologies associated with shell-boring invertebrates do not exert a major influence on condition index and growth of abalone. Clavier's (1992) study, however, did not include heavily infested individuals as they were 'old and slow growing'. Methods to combat shell infestations of molluscs entail the deposition of extra shell layers, and it is believed that molluscs afflicted with shell-boring organisms increase their metabolism accordingly (Ambariyanto \& Seed 1991). The reallocation of energy for shell repair is usually at the expense of somatic growth. This shift in energy budget is a common response to shell-boring organisms by abalone (Kojima \& Imajima 1982), and molluscs in general (Ambariyanto \& Seed 1991, Day \& Fleming 1992, Shepherd \& Breen 1992). This shift is likely to have contributed to the findings reported herein, as previously no host inflammatory responses or soft-tissue impairment were diagnosed on histological analysis of lesion-bearing Haliotis iris (Grindley et al. 1998).

Reduced growth capacity and weakened physiological condition entail longer grow-out periods which, together with damage to the commercially valuable shell, increased mortality and decreased reproductive capacity, will inevitably result in less efficient food turnover, higher labour costs (e.g. water-pumping) and loss of earnings for abalone farmers (Oakes \& Field 1996, Handley \& Bergquist 1997). Moreover, nearly all models used to describe the dynamics of wild abalone stocks require estimates of both growth and mortality (Poore 1972, Shepherd \& Breen 1992). The presence of lesions may therefore also have implications for the management of wild stocks in areas with high lesion prevalence (Grindley et al. 1998).

Acknowledgements. This research was funded with the help of a University of Otago Research Grant (99-739) to J.A.K. We thank Bill Dickson (Portobello Marine Laboratory) for his boat-driving skills, advice and support in the collection of the abalone, Dave Wilson for building the paua 'hotels', and the staff at the Portobello Marine Laboratory for watching over the abalone. Thanks to Dr. Steve Wing for his advice in analysing the growth data. Special thanks to Grant Hopkins, Murray Clarke, Amy West, Simon Muncaster and Adelle Heineman for diving assistance.

\section{LITERATURE CITED}

Ambariyanto, Seed R (1991) The infestation of Mytilus edulis (Linnaeus) by Polydora ciliata in the Conwy estuary, North Wales. J Molluscan Stud 57:413-424

Beverton RJH, Holt SJ (1993) On the dynamics of exploited fish populations. Fish and Fisheries, Series 11. Facsimile reprint of the report published by HMSO, London in 1957. Chapham \& Hall, London

Bucke D (1972) Histological techniques applicable to fish tissues. Symp Zool Soc 30:153-189

Clavier J (1992) Infestation of Haliotis tuberculata shells by Cliona celata and Polydora species. In: Shepherd SA, Tegner MJ, Guzmann del Próo SA (eds) Abalone of the world: biology, fisheries and culture. Supplementary papers. Fisheries Research Paper 24. Department of Fisheries of South Australia, Adelaide, p 16-20

Day RW, Fleming AE (1992) The determinants and measurement of abalone growth. In: Shepherd SA, Tegner MJ and Guzmán del Próo SA (eds) Abalone of the world: biology, fisheries and culture. Fishing News Books, Blackwell, Oxford, p 141-168 
Dunphy BJ (1999) Effects of shell boring organisms on the ecophysiology of paua (Haliotis iris) Martyn. MSc thesis, School of Biological Sciences, University of Auckland, Auckland

Friedman CS, Grindley RM, Keogh JA (1997) Isolation of a fungus from shell lesions of New Zealand abalone, Haliotis iris Martyn and $H$. australis Gmelin. Molluscan Res 18:313-324

Grindley RM (1997) Shell lesions in New Zealand Haliotis. MSc thesis, University of Otago, Dunedin

Grindley RM, Keogh JA, Friedman CS (1998) Shell lesions in New Zealand Haliotis spp. (Mollusca, Gastropoda). J Shellfish Res 17:805-811

Hahn KO (1989) Gonad reproductive cycles. In: Hahn KO (ed) Handbook of culture of abalone and other marine gastropods. CRC Press, Boca Raton, FL, p 13-40

Handley SJ, Bergquist PR (1997) Spionid polychaete infestations of intertidal Pacific oysters Crassostrea gigas (Thunberg), Mahurangi Harbour, northern New Zealand. Aquaculture 153:191-253

Kojima H, Imajima M (1982) Burrowing polychaetes in the shells of abalone Haliotis diversicolor aquatilus chiefly of the species of Polydora. Bull Jpn Soc Sci Fish 48:31-35

Lucas A, Benninger PG (1985) The use of physiological condition indices in marine bivalve aquaculture. Aquaculture $44: 187-200$

Editorial responsibility: Albert Sparks,

Seattle, Washington, USA
McShane PE, Naylor JR (1995) Small-scale spatial variation in growth, size at maturity and yield- and egg-per-recruit relations in the New Zealand abalone Haliotis iris. NZ J Mar Freshw Res 29:603-612

Nollens HH, Schofield JC, Keogh JA, Probert PK (2002) Evaluation of radiography, ultrasonography and endoscopy for detection of shell lesions in live abalone, Haliotis iris (Mollusca: Gastropoda). Dis Aquat Org 50:145-152

Oakes FR, Field RC (1996) Infestation of Haliotis rufescens shells by a sabellid polychaete. Aquaculture 140: $139-143$

Poore GCB (1972) Ecology of New Zealand abalones, Haliotis species (Mollusca: Gastropoda). 3. Growth. NZ J Mar Freshw Res 6:534-559

Sainsbury K J (1982) Population dynamics and fishery management of the paua, Haliotis iris. 1. Population, structure, growth, reproduction and mortality. NZ J Mar Freshw Res 16:147-161

Shepherd SA, Breen PA (1992) Mortality in abalone: its estimation, variability and causes. In: Shepherd SA, Tegner MJ, Guzmann del Proo SA (eds) Abalone of the world: biology, fisheries and culture. Fishing News Books, Blackwell, Oxford, p 276-304

Zar JH (1999) Simple linear regression. In: Zar JH (ed) Biostatistical analysis, 4th edn. Prentice Hall, Upper Saddle River, NJ, p 324-358

Submitted: May 28, 2002; Accepted: May 8, 2003

Proofs received from author(s): September 9, 2003 